\title{
Physico-Chemical Properties of Sesame (Sesamum indicum L.) Varieties Grown in Northern Area, Ethiopia
}

\author{
Haftom Zebib' ${ }^{1}$, Geremew Bultosa ${ }^{2}$, Solomon Abera ${ }^{3}$ \\ ${ }^{1}$ Abergelle Agricultural Research Center, Tigray Agricultural Research Institute, Abi-Adi, Ethiopia \\ ${ }^{2}$ Department of Food Science and Technology, Botswana College of Agriculture, Gaborone, Botswana \\ ${ }^{3}$ Department of Food Technology and Process Engineering, Haramaya University, Dire Dawa, Ethiopia \\ Email: hzhzebib6@gmail.com, gbultosa@bca.bw, solomon abera2001@yahoo.com
}

Received 30 January 2015; accepted 23 February 2015; published 25 February 2015

Copyright (C) 2015 by authors and Scientific Research Publishing Inc.

This work is licensed under the Creative Commons Attribution International License (CC BY). http://creativecommons.org/licenses/by/4.0/

(c) (i) Open Access

\begin{abstract}
This study was conducted to evaluate the physico-chemical properties of three sesame varieties: Adi, Bawnji and T-85. Sesame varieties showed significant $(\mathrm{p} \leq 0.05)$ differences on some physical properties, proximate, mineral, anti-nutritional (phytic acid) and antioxidant compositions. The average values of 1000 seed weight were ranged from $(2.74-3.16 \mathrm{~g})$ and true density from (1190.66 to $1215.58 \mathrm{~kg} \mathrm{~m}^{-3}$ ). The moisture (wb), crude protein, ash, fat, fiber, total carbohydrate, $\mathrm{Ca}, \mathrm{Zn}$ and $\mathrm{Fe}(\mathrm{db})$ were ranged: $3.17 \%-3.96 \%, 22.58 \%-24.27 \%, 4.46 \%-6.19 \%, 50.88 \%$ $52.67 \%, 5.60 \%$ - 6.26\%, 8.3\% - 11.69\%, 1172.08 - $1225.71 \mathrm{mg} / 100 \mathrm{~g}, 4.23$ - $4.45 \mathrm{mg} / 100 \mathrm{~g}$ and 10.2 $10.75 \mathrm{mg} / 100 \mathrm{~g}$, respectively. Phytic acid contents were ranged from 307.61 to $324.91 \mathrm{mg} / 100 \mathrm{~g}$, total phenolics from (23.16 - $25.69 \mathrm{mg} \mathrm{GAE} / \mathrm{g})$ and ferric ion reducing power value from (32.33 $34.53 \mu \mathrm{mol} / \mathrm{g}$ ) (db). The results were compared with some other sesame varieties grown worldwide. Results showed that Ethiopian sesame varieties were good source in nutrients and were functional foods for human nutrition and utilization.
\end{abstract}

\section{Keywords}

Anti-Nutritional, Antioxidant, Mineral, Physical Properties, Proximate Composition, Sesame Varieties

\section{Introduction}

Sesame (Sesamum indicum L.) is herbaceous annual plant belonging to the Pedaliaceae family [1]. Sesame seed

How to cite this paper: Zebib, H., Bultosa, G. and Abera, S. (2015) Physico-Chemical Properties of Sesame (Sesamum indicum L.) Varieties Grown in Northern Area, Ethiopia. Agricultural Sciences, 6, 238-246.

http://dx.doi.org/10.4236/as.2015.62024 
is also known as benniseed (Africa), benne (Southern United States), gingelly (India), gengelin (Brazil), sim-sim, semsem (Hebrew) and tila (Sanskrit) [2]. It is one of the world's important and oldest oilseed crops [3] [4] and has been used extensively for thousands of years as a seed of worldwide significance for edible oil, paste, cake, confectionary purposes and flour due to its highly stable oil contents, nutritious protein (rich in methionine, tryptophan and valine) and savory nutty roasted flavor [4] [5].

Oilseeds cover a total of 7.63\% (about 855,000 hectares) of the grain crop area and 3.83\% (6.6 million quintals) of yield production to the national grain production. For instance, Neoug (Niger seed), sesame and linseed covered $2.8 \%, 2.48 \%$ and $1.61 \%$ of grain crop area, respectively; and about $1.11 \%, 1.27 \%$ and $0.91 \%$ of the grain production, respectively [6]. Study reports indicate that Ethiopia is among the six producers of sesame seed, linseed and niger seed in the world [7]. The major sesame seed producing regions are situated in the North West and South West Ethiopian in Humera, North Gondar and Wollega [8]-[10].

Most of the sesame traded in the world is light seeded, but seed coats of local varieties can vary from white to buff, tan, gold, brown, reddish, gray and black [11]. Some of the variations in the seed are hundred seed weight that can range $0.11-0.46 \mathrm{~g}$ [12], protein $19 \%$ - 30\% [13] [14], oil 34.4\% - 59.8\% [13], carbohydrates $6.4 \%$ 21.0\% [15]. In Ethiopia, improved sesame seed varieties were developed through researches that have good disease resistance, improved yields, different oil composition, size and color [16]-[18].

Sesame contains important minerals and vitamins such as Ca, P, and Fe, niacin and thiamin [15] [19] [20]. It has also some potential of nutraceutical compounds such as phenolic and tocopherols with antioxidant activity that have significant effect on reducing the blood pressure, lipid profile and degeneration of vessels and an impact in reducing chronic diseases [21]-[23]. On the other hand, other chemical components such as anti-nutritional factors such as phytate, trypsin, $\alpha$-amylase inhibitors, lectin, and tannins are in existence in sesame seeds and can limit their utilization in the food system [24]-[27].

As sesame seed is nutritionally important in some parts of the world, few reports were documented about color, size and oil content of Ethiopian sesame seeds in the literature [17]-[19] and oil characteristics [28]. So, limited scientific research has been done on the physico-chemical composition of sesame varieties. The scientific information generated from this research could serve as an important input for production, marketing, food industry, human nutrition and maximum utilization, particularly for the benefits of sesame growing areas. The objective of this study was to investigate some physical properties, proximate, mineral, phytic acid, total phenolics and antioxidant power compositions.

\section{Materials and Methods}

\subsection{Experimental Site}

The experiment was conducted at Haramaya University from October 2011 to June 2012 in Food Science and Postharvest Technology laboratory for proximate, mineral, anti-nutritional and antioxidant compositions.

\subsection{Experimental Materials and Preparation}

The samples for the investigation were sesame (Sesamum indicum) varieties: adi, bawnji and T-85 were collected from Humera Agricultural Research Center (HuARC) in November 2011. Sesame seeds were cleaned manually to remove foreign matters, immature and damaged seeds. Then cleaned seeds were sorted out and crushed into smaller particles in a glass mortar and were stored in plastic bags at $4^{\circ} \mathrm{C}$ till used for the experiment.

\subsection{Physical Properties of Sesame Seed Varieties}

\subsubsection{Thousand Seed Weight}

Thousand seed weight was determined by using electronic grain counter (Numigral, CHOPIN). The mass of 1000 seeds counted were measured on electronic balance [29].

\subsubsection{True Density}

A group of 100 seeds with a known average weight was counted using electronic grain counter (Numigral, CHOPIN). Then true density was determined after measuring the volume occupied by 100 seeds [30].

Color - the color of sesame varieties were evaluated visually. 


\subsection{Chemical Analysis}

Moisture content (\%) was carried out by drying in oven (Model: 101-1A, Tianjin Taisite Instrument Co. Ltd.). Sample (about $3.0 \mathrm{~g}$ ) was dried at $100^{\circ} \mathrm{C}$ for $6 \mathrm{~h}$ [31].

Crude protein (\%)-sample (about $0.3 \mathrm{~g}$ ) was analyzed by micro-Kjeldahl method (digester: F30100184, SN: 111051, VELP Scientifica; distiller: F30100191, SN: 111526, Europe) [31] using urea as control. protein (\%) = $\mathrm{N}(\%) \times 6.25$.

Crude fat (\%) was determined by Soxhlet extraction (Model: EV 16, SN: 4002824, Germany) of sample (about $2.0 \mathrm{~g}$ ) using petroleum ether as a solvent [31].

Crude fiber (\%) was determined by taking about $3.0 \mathrm{~g}$ sample as portion of carbohydrate that resisted sulfuric acid (1.25\%) and $\mathrm{NaOH}(1.25 \%)$ digestion followed by sieving $(75 \mu \mathrm{m})$, washing, drying and ignition to subtract ash from fiber [31].

Total ash (\%) was determined by ashing about 3.0 g sample in a muffle furnace (Model: MF120, SN: 04-1524, Ankara Turkey) at $550^{\circ} \mathrm{C}$ until ashing complete (over $12 \mathrm{hrs)} \mathrm{[31].}$

Total carbohydrates (\%) was determined by difference: $100-(\%$ Moisture content $+\%$ Crude protein $+\%$ Crude fat $+\%$ Crude fiber $+\%$ Total ash).

Iron ( $\mathbf{m g} / \mathbf{1 0 0 g}$ ) was determined after digestion of sample (about $2.0 \mathrm{~g}$ ) by measuring absorbance of $\mathrm{Fe}^{2+}-1$, 10-phenanthroline red complex color at $510 \mathrm{~nm}$ using UV-VIS spectrophotometer [32]. The iron level was estimated from standard calibration curve $(0.0-10.0 \mu \mathrm{g} \mathrm{Fe} / \mathrm{ml})$ prepared from analytical grade iron wire.

Calcium (mg/100g) was determined after digestion of sample (about $2.0 \mathrm{~g}$ ) by Atomic Absorption spectrophotometer (AAS) at $422.7 \mathrm{~nm}$ by adding enough La stock solutions. Calcium level was then estimated from standard calibration curve $(5.0$ - $25.0 \mu \mathrm{g} \mathrm{Ca} / \mathrm{ml})$ prepared from analytical grade calcium carbonate $\left(\mathrm{CaCO}_{3}\right)$ [32].

Zinc (mg/100g) was determined after digestion of sample (about $2.0 \mathrm{~g}$ ) by Atomic Absorption Spectrophotometer (AAS) at $213.8 \mathrm{~nm}$ using air-acetylene as a source of flame for atomization [32]. Zinc level was then estimated from standard calibration curve $(0.5-3.0 \mu \mathrm{gn} / \mathrm{ml})$ prepared from $\mathrm{ZnO}$.

Phytic acid was determined through phytate phosphorus (Ph-P) analysis [33]. Sample (about $0.25 \mathrm{~g}$ ) was extracted with $12.5 \mathrm{ml}$ of $3 \%$ trichlorol lacetic acid (TCA) for $45 \mathrm{~min}$ in a water bath (GLS 400 water bath, England) with vortex mixing (REAX top, Germany) at ambient temperature $\left(23^{\circ} \mathrm{C}\right)$ and centrifuged $(4000 \mathrm{rpm} 10 \mathrm{~min})$ (Centrurion Scientific Model 1020 DE, United Kingdom). About $4 \mathrm{ml}$ of $\mathrm{FeCl}_{3} \cdot 6 \mathrm{H}_{2} \mathrm{O}$ was mixed to $10 \mathrm{ml}$ of the sample solution and the precipitate ferric phytate formed was analyzed for phytate phosphoru analyzed by measuring the absorbance at $822 \mathrm{~nm}$ using UV-Vis spectrophotometer (Model 6505, Genway LTD, U.K) [34]. The absorbance for sample was subtracted from the blank and phosphorus level was estimated from the calibration curve $(0.0-1.2 \mathrm{mg} / \mathrm{ml})$ prepared from $\mathrm{KH}_{2} \mathrm{PO}_{4}$. Then the phytic acid content was estimated by multiplying the amount of phytate-phosphorus by the factor 3.55 based on the empirical formula $\mathrm{C}_{6} \mathrm{P}_{6} \mathrm{O}_{24} \mathrm{H}_{18}(660 \mathrm{~g})$ and phytic phosphorus $\left(\mathrm{P}_{6}\right)$ molecular mass $(186 \mathrm{~g})$ (i.e., phytate $=\mathrm{P} \times 3.55$ ) and results were expressed as phytic acids in $\mathrm{mg}$ per $100 \mathrm{~g}(\mathrm{db})$.

Total phenolics content (TFC) was determined colorimetrically using Folin-Ciocalteau reagent, as described by [35]. Sample (about $0.4 \mathrm{~g}$ ) was extracted with $20 \mathrm{ml}$ of acidified methanol $(1 \% \mathrm{HCl}$ in methanol) for 1 hour at $25^{\circ} \mathrm{C}$, with vortex mixing at 5-minute intervals. Samples were centrifuged (Model 1020 D.E, UK) for 10 minutes at $1200 \times \mathrm{g}$. Three replicate sample extract supernatants $(0.5 \mathrm{ml})$ was mixed with $2.5 \mathrm{ml}$ of Folin-Cicalteau reagent and allowed to stand at $25^{\circ} \mathrm{C}$ for $8 \mathrm{~min}$. Then $7.5 \mathrm{ml}$ of $20 \%$ sodium bicarbonate solution was added to the mixture. After $2 \mathrm{~h}$ at $25^{\circ} \mathrm{C}$, absorbance was measured at $760 \mathrm{~nm}$ using a UV-visible spectrophotometer. A standard curve was prepared using various concentration of gallic acid and the results were reported as mg gallic acid equivalents/g of sample (db).

Antioxidant property analysis was measured by ferric ion reducing antioxidant power method as described by [36]. Sample (about $0.5 \mathrm{~g}$ ) was extracted with $80 \%$ methanol $(1 \mathrm{ml}$ ) on wrist action shaker for $2 \mathrm{~h}$. Sample extracted supernatants was mixed with $2.5 \mathrm{ml}$ of phosphate buffer $(0.2 \mathrm{M}, \mathrm{pH} 6.6)$ and $2.5 \mathrm{ml}$ potassium ferricyanide (1\%) was mixed followed by incubation at $50^{\circ} \mathrm{C}$ for $20 \mathrm{~min}$. After then $2.5 \mathrm{ml}$ of trichloroacetic acid solution (10\%) was added to mixture and was then centrifuged (Model 1020 D.E, U.K.) at $3000 \mathrm{~g}$ for $10 \mathrm{~min}$. The upper layer solution $(2.5 \mathrm{ml})$ was mixed with $2.5 \mathrm{ml}$ distilled water and $0.5 \mathrm{ml}$ ferric chloride $(0.1 \%)$. The absorbance of the mixture was measured at $700 \mathrm{~nm}$ immediately. Increased in the absorbance of the mixture is an indicator of increased reducing power. A standard curve was prepared using various concentration of ascorbic acid and the results were reported as $\mu$ mol ascorbic acid equivalents/g of sample (db). 


\subsection{Statistical Analysis}

Triplicate data were subjected to ANOVA [37] using Statistical Analysis System (SAS Institute and Cary NC) Version 9.0. Significant differences between means were determined with Duncan's multiple range tests at $\mathrm{p} \leq$ 0.05 .

\section{Results and Discussion}

\subsection{Some Physical Properties of Sesame Seed Varieties}

Table 1 shows color, thousands seeds weight and bulk density of the sesame seed varieties. Results showed significant ( $\leq 0.05$ ) differences in thousands seed weight between varieties. However, adi and T-85 varieties were not significantly different $(\mathrm{p} \geq 0.05)$ in their thousands seed weight from each other. The highest $(3.16 \mathrm{~g} /$ 1000seeds) thousands seed weight was recorded for adi variety and lowest (2.74 g/1000seeds) was for bawnji variety. These findings are similar with range reported (2.0 to $3.5 \mathrm{~g} / 1000$ seeds) by [38] and (2.76 - $3.96 \mathrm{~g} /$ 1000seeds) by [39] for 12 sesame genotypes cultivated in Turkey. [38] reported that the results may vary depending on variety and cultural conditions. There were significant $(\mathrm{p} \leq 0.05)$ differences in true density values of sesame seed varieties. True density of the sesame seed varieties had ranged from 1190.66 to $1215.62 \mathrm{~kg} \cdot \mathrm{m}^{-3}$. The result of current study is lower than $1224 \mathrm{~kg} \cdot \mathrm{m}^{-3}$ for Nigerian sesame seed reported by [40]. Information on the true sesame density is used to design sesame seed separation or cleaning processes. Slight color variability between sesame varieties was found. The sesame color of this study is with the class of reported by [41]. Seed color varied from white, yellow, reddish, brown or black [41]. [42] reported that genotypic effects may be responsible for the variation in seed characteristics.

\subsection{Proximate Composition of Sesame Seed Varieties}

Table 2 shows results of proximate composition of sesame varieties. Moisture content of the sesame varieties are significantly $(\mathrm{p} \leq 0.05)$ different and ranged $(3.17 \%-3.96 \%)$. The results obtained are in the range $(2.7 \%$ 4.7\%) reported by [42] for some varieties of Sudan and USA sesame genotypes but significantly lower than the range (5.12\% - 7.8\%) for 13 sesame accessions of south eastern Nigeria [43]. Crude fiber content was observed to be significantly $(\mathrm{p} \leq 0.05$ ) higher in the adi and T-85 varieties 6.26 and $6.09 \%$ respectively than bawnji variety (5.6\%). These values are in the range 3.2\% - 10.0\% reported by [44] but are higher than the range $3.3 \%-4.66 \%$ reported by [42] for Sudan varieties and USA genotypes. Fiber in the diet is important as it helps to maintain human health by reducing blood cholesterol and glucose level in the body [45].

Ash content was observed significantly $(\mathrm{p} \leq 0.05)$ different between sesame varieties. T-85 had the highest $(6.19 \mathrm{~g} / 100 \mathrm{~g})$ ash content and least was for bawnji (4.46 g/100g). [46] reported ash values to be between 1.4 and $6.6 \mathrm{~g} / 100 \mathrm{~g}$ for Saudi Arabia and foreign varieties (Lebanese, Indian and World collection), which is similar with the results of this study. Chemical composition of seeds can be affected not only by the genotype but also by agro-climatic conditions [47] [48]. High level of ash makes the oilseed a good source of mineral nutrition to the consumer [49].

Fat content had varied significantly $(\mathrm{p} \leq 0.05)$ between varieties in Table 3 . The highest fat $(52.67 \%)$ was obtained in bawnji followed by T-85 (51.18\%) and adi (50.88\%). [51] reported the oil content can range from $43.4 \%$ to $58.8 \%$ for 42 strains of sesame with the highest oil content found in white-seeded strain. [52] reported oil content in Saudi and Indian sesame seeds ranging from $43.2 \%$ to $54.0 \%$. Both the above results are consistent with the result of current study. [53] and [54] reported a significantly higher oil content (54.26\% - 63.25\%) in the Turkish sesame seeds of the TSP 933749 line selected from the TSP 9337 population, as compared to that of

Table 1. Some physical properties of sesame seed varieties.

\begin{tabular}{ccccc}
\hline & & Varieties & Bawnji & T-85 \\
\cline { 2 - 4 } Parameters & Adi & White & Dull white & $2.98 \pm 0.09^{\mathrm{c}}$ \\
1000 seeds weight $(\mathrm{g})$ & White & $2.74 \pm 0.12^{\mathrm{b}}$ & $1215.58 \pm 0.53^{\mathrm{b}}$ & $1213.62 \pm 0.38^{\mathrm{c}}$ \\
True density $\left(\mathrm{kg} \cdot \mathrm{m}^{-3}\right)$ & $3.16 \pm 0.09^{\mathrm{a}}$ & $1190.66 \pm 0.37^{\mathrm{a}}$ & \\
\hline
\end{tabular}


Table 2. Proximate composition of three sesame varieties compared with other world sesame varieties.

\begin{tabular}{cccccccc}
\hline Composition (\%) & Adi & Bawnji & T-85 & $\begin{array}{c}\text { Sudanese }^{[42]} \\
\text { genotype }\end{array}$ & $\begin{array}{c}\text { USA }^{[42]} \\
\text { genotype }\end{array}$ & $\begin{array}{c}\text { Egyptian }^{[2]} \\
\text { varieties }\end{array}$ & $\begin{array}{c}\text { Nigrian }^{[50]} \\
\text { sesame }^{[3}\end{array}$ \\
\hline Moisture & $3.17 \pm 0.05^{\mathrm{a}}$ & $3.40 \pm 0.04^{\mathrm{b}}$ & $3.96 \pm 0.15^{\mathrm{c}}$ & 3.75 & 3.71 & 2.96 & 1.91 \\
Crude fiber & $6.26 \pm 0.10^{\mathrm{a}}$ & $5.60 \pm 0.08^{\mathrm{b}}$ & $6.09 \pm 0.08^{\mathrm{c}}$ & 3.76 & 4.03 & 7.03 & 3.56 \\
Total ash & $5.42 \pm 0.01^{\mathrm{a}}$ & $4.46 \pm 0.09^{\mathrm{b}}$ & $6.19 \pm 0.07^{\mathrm{c}}$ & 9.00 & 8.82 & 3.25 & 5.83 \\
Crude fat & $50.88 \pm 0.24^{\mathrm{a}}$ & $52.67 \pm 0.47^{\mathrm{b}}$ & $51.18 \pm 0.22^{\mathrm{b}}$ & 47.37 & 47.18 & 58.52 & 52.7 \\
Crude protein & $22.58 \pm 0.18^{\mathrm{a}}$ & $22.49 \pm 0.21^{\mathrm{a}}$ & $24.27 \pm 0.38^{\mathrm{b}}$ & 34.41 & 37.24 & 22.30 & 26.23 \\
Carbohydrate & $11.69 \pm 0.31^{\mathrm{a}}$ & $11.39 \pm 0.66^{\mathrm{a}}$ & $8.31 \pm 0.25^{\mathrm{b}}$ & 1.80 & 1.60 & 5.64 & 9.77 \\
\hline
\end{tabular}

Table 3. Mineral composition of three sesame varieties compared with other world sesame varieties.

\begin{tabular}{|c|c|c|c|c|c|c|c|c|c|c|}
\hline $\begin{array}{l}\text { Minerals } \\
\text { (mg/100g) }\end{array}$ & Adi & Bawnji & T-85 & $\begin{array}{l}\text { Sudanese }^{[42]} \\
\text { genotypes }\end{array}$ & $\begin{array}{l}\text { USA }^{[42]} \\
\text { genotypes }\end{array}$ & $\begin{array}{l}\text { White }{ }^{[46]} \\
\text { Saudi } \\
\text { varieties }\end{array}$ & $\begin{array}{l}\text { World }^{[69]} \\
\text { collection }\end{array}$ & $\begin{array}{l}\text { Indian }^{[64]} \\
\text { varieties }\end{array}$ & $\begin{array}{c}\text { Lebanese }^{[62]} \\
\text { varieties }\end{array}$ & $\begin{array}{c}{ }^{2]} \text { Japanese }^{[68]} \\
\text { brown }\end{array}$ \\
\hline $\mathrm{Ca}$ & $1182.79 \pm 0.21^{\mathrm{a}}$ & $1172.08 \pm 0.35^{b}$ & $1225.71 \pm 0.76^{c}$ & 1030 & 650 & 1228 & 1160 & 1450 & 1200 & 1200 \\
\hline $\mathrm{Zn}$ & $4.37 \pm 0.01^{\mathrm{a}}$ & $4.23 \pm 0.05^{\mathrm{b}}$ & $4.45 \pm 0.01^{\mathrm{c}}$ & - & - & 3.6 & - & - & - & - \\
\hline $\mathrm{Fe}$ & $10.51 \pm 0.0^{\mathrm{a}}$ & $10.24 \pm 0.04^{\mathrm{b}}$ & $10.75 \pm 0.06^{\mathrm{c}}$ & 3.09 & 2.88 & 10.4 & 10.50 & 10.5 & 10.4 & 9.6 \\
\hline
\end{tabular}

the current study result. The differences might be attributed to the different regions of seeds production [48]. Variation in the oil yield of sesame may be due to variation in variety, soil type, climatic, maturity of plant, the harvesting time of the seeds and the extraction method used [55] [56].

There is a significant $(\mathrm{p} \leq 0.05)$ difference in the protein content between varieties. Adi and bawnji varieties had no significant $(\mathrm{p} \geq 0.05)$ differences in their protein content. The highest protein content $(24.27 \%)$ was recorded in T-85 while the lowest (22.49\%) was for bawnji. This results is consistent with range (18\% - 25\%) reported by [15] but are lower than those reported by [42] for Sudan varieties and USA genotypes (32.5\% - 40.0\%) and by [43] for 13 sesame accessions of Nigeria (27.50\% - 45.68\%). [39] found protein content (19.81\% to 24.45\%) in Turkey's sesame genotype. Varietal differences in protein content may have been attributed to soil, climate, strain and fertilizer treatment [48] [52] [57]. Carbohydrate contents of adi and bawnji varieties were $11.69 \%$ and $11.39 \%$ respectively and significantly higher than that of T-85 (8.31\%). Carbohydrate content had ranged $(8.31 \%-11.69 \%)$ between varieties studied which is in agreement with range (6.4\% - 21.0\%) reported by [16] but are higher than the range $1.05 \%-2.88 \%$ reported by [42] for Sudan varieties and USA genotypes. The highest carbohydrate values (27.90\% - 45.15\%) were reported in 13 sesame accession of Nigeria by [43]. Compositional differences can exist among the different varieties of sesame seeds, and among the sesame variety grown in different countries [58]. Further studies by [59] on some legume crops reported that there might be differences between varieties of the same species.

\subsection{Mineral Composition of Sesame Seed Varieties}

Calcium, zinc and iron contents had varied significantly $(\mathrm{p} \leq 0.05)$ between varieties in Table 3 . T-85 variety had the highest Ca (1225.71 mg/100g) and the lowest was for bawnji (1172.08 mg/100g). The calcium content of this study is lower than $1450 \mathrm{mg} / 100 \mathrm{~g}$ reported by [60] and [61] in some Indian sesame varieties. However, some Lebanese sesame varieties exhibited the lowest $(228.3 \mathrm{mg} / 100 \mathrm{~g})$ calcium content [62]. The current study results are in the range 600 - $2000 \mathrm{mg} / 100 \mathrm{~g}$ for two Egyptian sesame seed varieties reported by [63]. The highest zinc content $(4.45 \mathrm{mg} / 100 \mathrm{~g})$ was recorded in T-85 variety while the lowest content $(4.23 \mathrm{mg} / 100 \mathrm{~g}$ ) was found in bawnji. This zinc content found is higher than the range $(0-3.8 \mathrm{mg} / 100 \mathrm{~g})$ reported by [46] for Saudi Arabia and varieties (Lebanese, Indian, Nigerian and World collection). The highest iron content was found for T-85 variety and the lowest content was for bawnji variety. The results obtained in this work are in the range (9.6 $11.7 \mathrm{mg} / 100 \mathrm{~g}$ ) previously reported by [60] [62] [64]. [65] reported that a wide variation in ash content of sesame varieties exists which is an index of total mineral matter present in the seeds. 
Table 4. Anti-nutritional and antioxidants of sesame varieties compared with other world sesame.

\begin{tabular}{ccccccccc}
\hline Components & Adi & Bawnji & T-85 & $\begin{array}{c}\text { Iranian }^{[23]} \\
\text { sesame } \\
\text { varieties }\end{array}$ & $\begin{array}{c}\text { Indian }^{[70]} \\
\text { sesame cake } \\
\text { extracts }\end{array}$ & $\begin{array}{c}\text { USA }^{[67]} \\
\text { black } \\
\text { sesame }\end{array}$ & $\begin{array}{c}\text { USA }^{[67]} \text { Nigerian }^{[50]} \\
\text { soybean } \\
\text { sesame }\end{array}$ \\
\hline Phytic acid (mg/100g) & $324.61 \pm 1.73^{\mathrm{a}}$ & $307.61 \pm 1.73^{\mathrm{b}}$ & $324.91 \pm 1.73^{\mathrm{a}}$ & - & - & $379-494380-415$ & 315.90 \\
TPC $(\mathrm{mg} \mathrm{GAE} / \mathrm{g})$ & $23.16 \pm 0.65^{\mathrm{a}}$ & $24.84 \pm 0.42^{\mathrm{b}}$ & $25.69 \pm 0.85^{\mathrm{c}}$ & $20.1-70.97$ & 26.20 & - & - & - \\
FRAP $(\mu \cdot \mathrm{mol} / \mathrm{g})$ & $32.33 \pm 0.56^{\mathrm{a}}$ & $33.31 \pm 0.37^{\mathrm{b}}$ & $34.53 \pm 0.32^{\mathrm{c}}$ & $30.00-97.00$ & 161.04 & - & - & - \\
\hline
\end{tabular}

\subsection{Anti-Nutritional and Antioxidant Contents of Sesame Seed Varieties}

Table 4 shows anti-nutritional and antioxidant contents of raw sesame varieties. Results showed significant ( $\mathrm{p} \leq$ 0.05) differences in phytic acid contents between varieties. T-85 (324.91 mg/100g) and adi (324.61 mg/100g) had significantly higher than bawnji $(307.61 \mathrm{mg} / 100 \mathrm{~g})$. The results obtained are lower than reported by [66] for black sesame seeds (379 - $494 \mathrm{mg} / 100 \mathrm{~g})$. Similar phytic acid value (315.9 mg/100g) was obtained in sesame seed by [50]. [67] found higher amount of phytic acid in bigger size whole white sesame (62.67 $\mathrm{mg} / 100 \mathrm{~g})$ than in small size whole black sesame $(52.60 \mathrm{mg} / 100 \mathrm{~g})$ which are lowest values when compared with the current study results, who reported that the amount of the phytic acid depends on the size of seed. Also, [46] had reported that the phytic acid contents of the sesame varieties were affected by genotypes. The total phenolic content and antioxidant power value had varied significantly $(\mathrm{p} \leq 0.05)$ between the varieties. The highest TPC (25.69 mg GAE/g) was in T-85 variety and the lowest (23.16 mg GAE/g) was for adi variety. The result found in this work are in the range of (20.1 - $70.95 \mathrm{mg} \mathrm{GAE/g)} \mathrm{reported} \mathrm{by} \mathrm{[23]} \mathrm{for} \mathrm{eight} \mathrm{Iranian} \mathrm{sesame} \mathrm{varieties} \mathrm{and}$ (73.74 to $128.80 \mathrm{mg}$ tannic acid/100g) for raw, roasted, soaked roasted, micro waved roasted and defatted meal of sesame varieties by [63]. The highest reducing power value $(34.53 \mu \mathrm{mol} / \mathrm{g})$ was recorded in T-85 variety and the lowest was recorded in adi $(33.31 \mu \mathrm{mol} / \mathrm{g})$. The results obtained are in the range of (30.00 - $97.00 \mu \mathrm{mol} / \mathrm{g}$ ) reported by [23] for eight Iranian sesame varieties but higher than the range value $25.31-27.21 \mu \mathrm{mol} / \mathrm{g}$ for two Egyptian raw sesame varieties by [63].

\section{Conclusion}

The local Ethiopian sesame varieties are a good source rich in protein, crude fiber, minerals, crude fat, phenols and reducing power values when compared with other world grown sesame varieties. T-85 variety shows quite good protein, mineral and anti-oxidant compositions when compared to each other. But more research is required in processing to reduce phytic acid content of the seed to utilize nutrients efficiently. And sesame seeds should be processed in different product and blended with concentrated fruits to utilize as functional food for human nutrition. It is concluded that a better understanding of the physico-chemical nature of sesame seed varieties is important for production, nutrition, marketing, food application and maximum utilization.

\section{Acknowledgements}

The authors greatly thank NARF Functional Food Project (NARF/CR/01/004/09) at Food Science and Postharvest Technology (FSPT) Department for granting us financial support and Humera Agricultural Research Centre (HuARC) for providing sesame varieties. The Center of Research on Grain Quality, Processing and Technology Transfer (CRGQPTT) at FSPT department, Haramaya University is acknowledged for supporting with facilities in this work.

\section{References}

[1] Sugano, M. and Akinmoto, K.A. (1993) Multifunctional Gift from Nature. Journal of the Chinese Society of Animal Science, 18, 1-11.

[2] Hassan, M.A.M. (2012) Studies on Egyptian Sesame Seeds (Sesamum Indicum L.) and Its Products 1-Physicochemical Analysis and Phenolic Acids of Roasted Egyptian Sesame Seeds (Sesamum indicum L.). World Journal of Dairy \& Food Sciences, 7, 195-201.

[3] Sontag, N.O.V. (1979) Composition and Characteristics of Individual Fats and Oils. In: Swern D., Ed., Bailey’s Industrial Oil and Fat Products, Vol. 1, W. Johns and Sons, New York, 15.

[4] Biswas, T.K., Sana, N.K. Padal, R.K. and Huque, E.M. (2001) Biochemical Study of Some Oil Seeds (Brassica, Se- 
same and Linseed). Pakistan Journal of Biological Science, 4, 1002-1005. http://dx.doi.org/10.3923/pjbs.2001.1002.1005

[5] Shyu, Y.S. and Hwang, L.S. (2002) Antioxidative Activity of the Crude Extract of Lignin Glycosides from Unroasted Burma Black Sesame Meal. Food Research International, 35, 357-365. http://dx.doi.org/10.1016/S0963-9969(01)00130-2

[6] CSA (Central Statistical Authority) (2009) Federal Democratic Republic Ethiopia: Central Statistics Agency. Agricultural Sample survey 2008/9 (2001 E.C) (Sep-Dec 2008). Vol. I. Report on Area and Production of Crops (Private Peasant Holdings, Meher Season). Statistical Bulletin No.: 446, Addis Ababa, 12-17.

[7] Wijnands, J. Biersteker, J. and van Loo E.N. (2009) Oilseeds Business Opportunities in Ethiopia. Public Private Partnership, The Hague, 1-60.

[8] Wijnands, J., Biersteker, J. and Hiel, R. (2007) Oilseeds Business Opportunities in Ethiopia. Survey Report, Ministry of Agriculture, Nature and Food Quality, The Hague, 8-20.

[9] Dawit, A. and Meijerink, G. (2010) The Ethiopian Commodity Exchange (ECX): An Overview. A Report Prepared by Ethiopian Pulses, Oil Seeds and Spices Processors Exporters Association, Public Private Partnership and Wageningen University, Netherland, 5-34. www.dgis.wur.nl/NR/rdonlyres/.../Report4Alemu280610.pdf

[10] CSA (Central Statistical Agency) (2013/14) Agricultural Sample Survey for 2013/14: Report on Area and Production of Major Crops for Private Peasant Holdings, Meher Season. Statistical Bulletin No 532, Addis Ababa.

[11] Langham, D.R. and Wiemers, T. (2002) Progress in Mechanizing Sesame in the U.S through Breeding. In: Janick, J. and Whipkey, A., Eds., Trends in New Crops and New Uses, ASHS Press, Alexandria, 157-173.

[12] SESACO (2007) Mission Statement.

[13] Ashri, A. (1998) Sesame Breeding. Plant Breeding Reviews, 16, 179-228.

[14] Elleuch, M., Besbes, S., Roiseux, O., Blecker, C. and Attia, H. (2007) Quality Characteristics of Sesame Seeds and ByProducts. Food Chemistry, 103, 641-650. http://dx.doi.org/10.1016/j.foodchem.2006.09.008

[15] Abu-Jdayil, B., Al-Malah, K. and Asoud, H. (2002) Rheological Characterization of Milled Sesame (Tehineh). Food Hydrocolloids, 16, 55-61. http://dx.doi.org/10.1016/S0268-005X(01)00040-6

[16] ARARI (Amhara Regional Agricultural Research Institute) (2005) Sesame Development Training Manual. Bahir Dar, Ethiopia.

[17] BARD (Bureau of Agriculture and Rural Development) (2007) Annual Reports. Addis Ababa, 3 p.

[18] Zerihun, J. (2012) Sesame (Sesamum indicum L.) Crop Production in Ethiopia: Trends, Challenges and Future Prospects. Science, Technology and Arts Research Journal, 1, 1-7.

[19] Ojiako, O.A., Igwe, C.U., Agha, N.C., Ogbuji, C.A. and Onwuliri, V.A. (2010) Protein and Amino Acid Compositions of Sphenostylis Stenocarpa, Sesamum indicum, Monodora Myristica and Afzelia Africana Seeds from Nigeria. Pakistan Journal of Nutrition, 9, 368-372. http://dx.doi.org/10.3923/pjn.2010.368.372

[20] USDA (United States Department of Agriculture) (2003) Nutrient Database for Standard Reference. Washington DC.

[21] Abou-Gharbia, H.A., Shahidi, F., Adel, A., Shehata, Y. and Youssef, M.M. (1997) Effects of Processing on Oxidative Stability of Sesame Oil Extracted from Intact Seeds. Journal of the American Oil Chemists' Society, 74, $215-221$. http://dx.doi.org/10.1007/s11746-997-0126-9

[22] Mohamed, H.M. and Awatif, I.I. (1998) The Use of Sesame Oil Unsaponifiable Matter as a Natural Antioxidant. Food Chemistry, 62, 269-276. http://dx.doi.org/10.1016/S0308-8146(97)00193-3

[23] Jannat, B., Oveisi, M.R., Sadeghi, N., Hajimahmoodi, N., Behzad, M., Choopankari, E. and Behfar, A.A. (2010) Effects of Roasting Temperature and Time on Healthy Nutraceuticals of Antioxidants and Total Phenolic Content in Iranian Sesame Seeds (Sesamum indicum L.). Iranian Journal of Environmental Health Science and Engineering, 7, 97102.

[24] Moran, E.T., Pepper, W.F. and Summers, J.D. (1969) Processed Feather and Hog Hair Meals as Sources of Dietary Protein for the Laying Hen with Emphasis on Their Use in Meeting Maintenance Needs. Poultry Science, 48, 12451251. http://dx.doi.org/10.3382/ps.0481245

[25] Wu, Y.V. and Inglett, G.E. (1974) Denaturation of Plant Proteins Related to Functionality and Food Applications. Journal of Food Science, 39, 218-225. http://dx.doi.org/10.1111/j.1365-2621.1974.tb02861.x

[26] Liener, I.E. (1994) Implications of Antinutritional Components in Soybean Foods. Critical Reviews in Food Science and Nutrition, 34, 31-67. http://dx.doi.org/10.1080/10408399409527649

[27] Adegnwa, M.O., Adebowale, A.A. and Solano, E.O. (2012) Effect of Thermal Processing on Biochemical Composition, Anti-Nutritional Factors and Functional Properties of Beniseed (Sesamum indicum) Flour. American Journal of Biochemistry and Molecular Biology, 2, 175-182. http://dx.doi.org/10.3923/ajbmb.2012.175.182 
[28] Seegeler, C.J.P. (1983) Oil Plants in Ethiopia: Their Taxonomy and Agricultural Significance. Centre for Agricultural Publishing and Documentation, Wageningen.

[29] ISTA (1985) International Rules for Seed Testing. Seed Science and Technology, 13, 307-520.

[30] Dutta, S.K., Nema, V.K. and Bhardwaj, R.K. (1972) Physical Properties of Gram. Journal of Agricultural Engineering Research, 12, 128-137.

[31] AOAC (Association of Official Analytical Chemists) (1995) Official Methods of Analysis. 16th Edition, AOAC, Arlington.

[32] AACC (American Association of Cereal Chemists) (2000) Approved Method of the American Association of Cereal Chemists, Inc., Eagan.

[33] Wheeler, E.L. and Ferrel, R.E. (1971) A Method for Phytic Acid Determination in Wheat and Wheat Fractions. Cereal Chemistry, 48, 312-320.

[34] Morrison, W.R. (1964) A Fast, Simple and Reliable Method for the Microdetermination of Phosphorus in Biological Materials. Analytical Biochemistry, 7, 218-224. http://dx.doi.org/10.1016/0003-2697(64)90231-3

[35] Singleton, V.L. and Rossi, J.A. (1965) Colorimetry of Total Phenolics with Phosphomolybdic-Phosphotungstic Acid Reagents. American Journal of Enology and Viticulture, 16, 144-158.

[36] Zhao, H., Fan, W., Dong, J., Lu, J., Chen, J., Shan, L., Lin, Y. and Kong, W. (2008) Evaluation of Antioxidant Activities and Total Phenolic Contents of Typical Malting Barley Varieties. Food Chemistry, 107, 296-304. http://dx.doi.org/10.1016/j.foodchem.2007.08.018

[37] Gomez, K.A. and Gomez, A.A. (1984) Statistical Procedures for Agricultural Research. John Wiley and Sons Inc., New Work.

[38] Eckey, E.W. (1954) Vegetable Fats and Oils. Reinhold Publishing Corp., New York.

[39] Ozkan, A., Curat, D. and Kulak, M. (2012) Morphological Properties and Chemical Compositions of Some Sesame (Sesamum indicum L.) Populations Cultivated in Kilis, Turkey. African Journal of Agricultural Research, 7, 30293033.

[40] Tunde-Akintunde, T.Y. and Akintunde, B.O. (2004) Some Physical Properties of Sesame Seed. Biosystems Engineering, 88, 127-129. http://dx.doi.org/10.1016/j.biosystemseng.2004.01.009

[41] Olayanju, T., Akinoso, R. and Oresanya, M.O. (2006) Effect of Worm Shaft Speed and Moisture Content on Oil Recovery from Beniseed. Agricultural Engineering International: The CIGR Ejournal Manuscript FP 06008 , Vol. VIII.

[42] El-Khier, K.S., Ishag, K.E.A. and Yagoub, A.E.A. (2008) Chemical Composition and Oil Characteristics of Sesame Seed Varieties Grown in Sudan. Research Journal of Agriculture and Biological Sciences, 14, 1-6.

[43] Ogbonna, P.E. and Ukaan, S.I. (2013) Chemical Composition and Oil Quality of Seeds of Sesame Accessions Grown in the Nsukka Plains of South Eastern Nigeria. African Journal of Agriculture Research, 8, 797-803.

[44] Obiajunwa, E.T., Adebiyi, F.M. and Omode, P.E. (2005) Determination of Essential Minerals and Trace Elements in Nigerian Sesame Seeds Using TXRF Technique. Pakistan Journal of Nutrition, 4, 393-395. http://dx.doi.org/10.3923/pjn.2005.393.395

[45] Bello, M.O.I., Flade, O.S., Adewusi, S.R.A. and Olawore, N.O. (2008) Studies on the Chemical Composition and Antinutrients of Some Lesser Known Nigerian Fruits. African Journal of Biotechnology, 7, 3972-3979.

[46] Mohammed, N.A., Basahy, Y. and Sher, H. (2011) Physico-Chemical Analysis and Mineral Composition of Some Sesame Seeds (Sesamum indicum L.) Grown in the Gizan Area of Saudi Arabia. Journal of Medicinal Plants Research, 5, 270-274.

[47] Lyon, C.K. (1972) Sesame: Current Knowledge of Composition and Uses. Journal of the American Oil Chemists' Society, 49, 245-249. http://dx.doi.org/10.1007/BF02582586

[48] Kanu, P.J. (2011) Biochemical Analysis of Black and White Sesame Seeds from China. American Journal of Biochemistry and Molecular Biology, 1, 145-157. http://dx.doi.org/10.3923/ajbmb.2011.145.157

[49] Afolabi, I.S. (2008) Chemical Qualities of Oils from Some Fresh and Market Vegetable Crops within Kwara State of Nigeria. Biochemistry, 20, 71-75.

[50] Olagunju, A.I. and Ifesan, B.O.T. (2013) Nutritional Composition and Acceptability of Cookies Made from Wheat Flour and Germinated Sesame (Sesamum indicum) Flour Blends. British Journal of Applied Science \& Technology, 3 702-713. http://dx.doi.org/10.9734/BJAST/2013/3547

[51] Tashiro, T., Fakuda, Y., Osawa, T. and Namiki, M. (1990) Oil and Minor Components of Sesame (Sesamum indicum) Strains. Journal of the American Oil Chemists' Society, 67, 508-511. http://dx.doi.org/10.1007/BF02540757

[52] Bahkali, A.H., Hussain, M.A. and Basahy, A.Y. (1998) Protein and Oil Composition of Sesame Seeds (Sesamum indicum, L.) Grown in the Gizan Area of Saudi Arabia. International Journal of Food Sciences and Nutrition, 49, 409-414. 
http://dx.doi.org/10.3109/09637489809086419

[53] Baydar, H., Turgut, I. and Turgut, K. (1999) Variation of Certain Characters and Line Selection for Yield, Oleic and Linoleic Acids in the Turkish Sesame (Sesamum indicum L.) Populations. Journal of Agricultural Forestry, 23, 431441.

[54] Unal, M.K. and Yalcsn, H. (2008) Proximate Composition of Turkish Sesame Seeds and Characterization of Their Oils. Grasas y Aceites, 59, 23-26.

[55] Egbekun, M.K. and Ehieze, M.U. (1997) Proximate Composition and Functional Properties of Full Fat and Defatted Beniseed (Sesamum indicum L.) Flour. Plant Foods for Human Nutrition, 51, 35-41. http://dx.doi.org/10.1023/A:1007966103484

[56] Rahman, M.S., Hossain, M.A., Ahmed, G.M. and Uddin, M.M. (2007) Studies on the Characterization, Lipids and Glyceride Composition of Sesame (Sesamum indicum L.) Seed Oil. Bangladesh Journal of Science and Indian Research, 42, 67-74.

[57] Kuzayli, M.V., Cowan, J.W. and Sabry, Z.I. (1966) Nutritive Value of Middle Eastern Food Stuffs II. Composition of Pulses, Seeds, Nuts and Cereal Products of Lebanon. Journal of the Science of Food and Agriculture, 17, 82-84. http://dx.doi.org/10.1002/jsfa.2740170208

[58] Johnson, L.A., Suleiman, T.M. and Lusas, E.W. (1979) Sesame Protein: A Review and Prospectus. Journal of the American Oil Chemists' Society, 56, 463-468. http://dx.doi.org/10.1007/BF02671542

[59] Evans, R.J. and Bandemer, S.L. (1967) Nutritive Value of Some Oilseed Proteins. Cereal Chemistry, 44, 417-426.

[60] Gopalan, C., Ramasastri, B.V. and Balasubramanian, S.C. (1982) Nutritive Value of Indian Foods: National Institute of Nutrition. Indian Council of Medical Research, Hyderabad.

[61] Sher, H., Al-Yemeni, M., Bahkali, A.H.A. and Sher, H. (2010) Effect of Environmental Factors on the Yield of Selected Mushroom Species Growing in Two Different Agro Ecological Zones. Saudi Journal of Biological Sciences, 17, 321-326. http://dx.doi.org/10.1016/j.sjbs.2010.06.004

[62] Pellett, P.L. and Shadarevian, S. (1970) Food Composition, Tables for Use in the Middle East. 2nd Edition, American University of Beirut, Beirut.

[63] Hassan, M.A.M. (2013) Studies on Egyptian Sesame Seeds (Sesamum indicum L.) and Its Products. 3. Effect of Roasting Process on Gross Chemical Composition, Functional Properties, Antioxidative Components and Some Minerals of Defatted Sesame Seeds Meal (Sesamum indicum L.). World Journal of Dairy \& Food Sciences, 8, 51-57.

[64] Deosthale, Y.G. (1981) Trace Element Composition of Common Oilseeds. Journal of the American Oil Chemists' Society, 58, 988-990. http://dx.doi.org/10.1007/BF02659779

[65] Dhawan, S., Singhvi, S.C. and Sim Lot, M.M. (1972) Studies on the Quality of Sesame Seed and Oil. I. Varietal Differences in the Quantity and Quality of Oil. Journal of Food Science and Technology, 9, 23-25.

[66] Thunyarat, P., Suparerk, T. and Jeff, R. (2012) Determination of Phytic Acid in Soybeans and Black Sesame Seeds. Bangkok, Sunnyvale, 5 p.

[67] Makinde, F.M. and Akinoso, R. (2013) Nutrient Composition and Effect of Processing Treatments on Anti-Nutritional Factors of Nigerian Sesame (Sesamum indicum Linn) Cultivars. International Food Research Journal, 20, 2293-2300.

[68] Naiki, M. (1995) The Chemistry and Physiological Functions of Sesame. Food Reviews International, 11, $281-329$. http://dx.doi.org/10.1080/87559129509541043

[69] Weiss, E.A. (1983) Oilseed Crops. Longman, London, New York.

[70] Reshma, M.V., Namitha, L.K., Sundaresan, A. and Kiran, C.R. (2012) Total Phenol Content, Antioxidant Activities and $\alpha$-Glucosidase Inhibition of Sesame Cake Extracts. Journal of Food Biochemistry, 22, 1-9. 
Scientific Research Publishing (SCIRP) is one of the largest Open Access journal publishers. It is currently publishing more than 200 open access, online, peer-reviewed journals covering a wide range of academic disciplines. SCIRP serves the worldwide academic communities and contributes to the progress and application of science with its publication.

Other selected journals from SCIRP are listed as below. Submit your manuscript to us via either submit@scirp.org or Online Submission Portal.
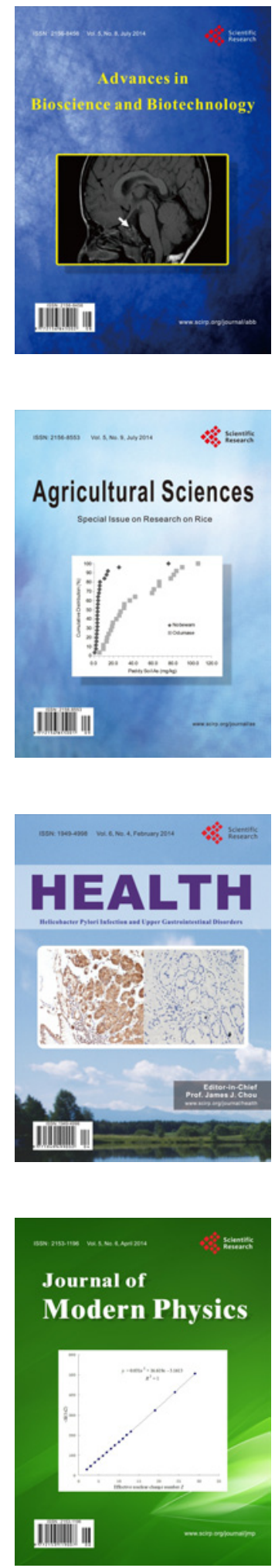
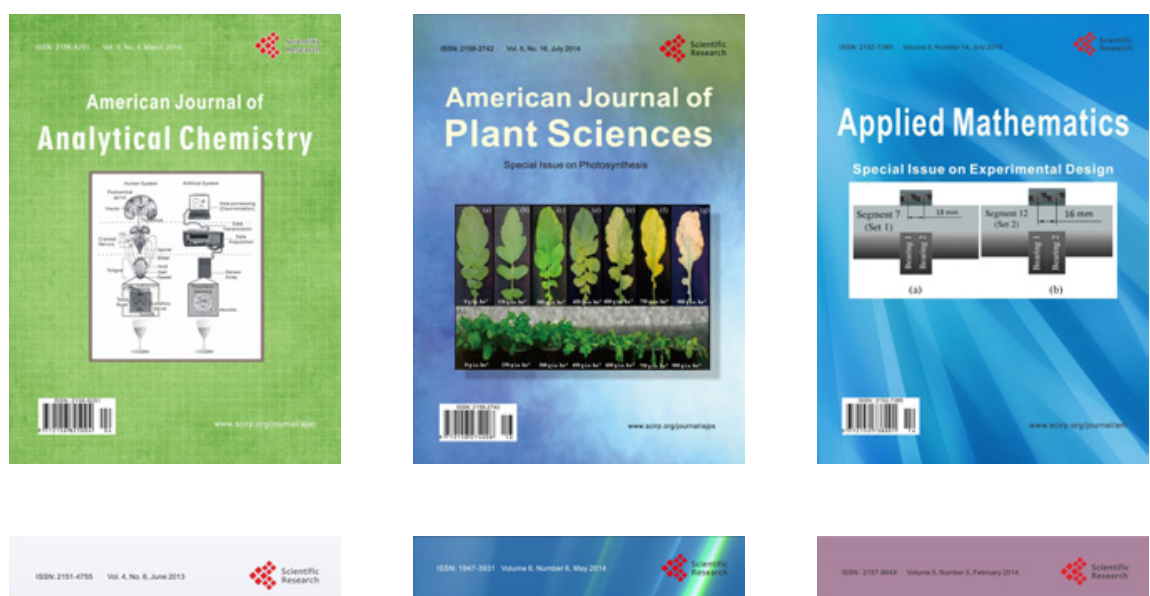

Creative Education
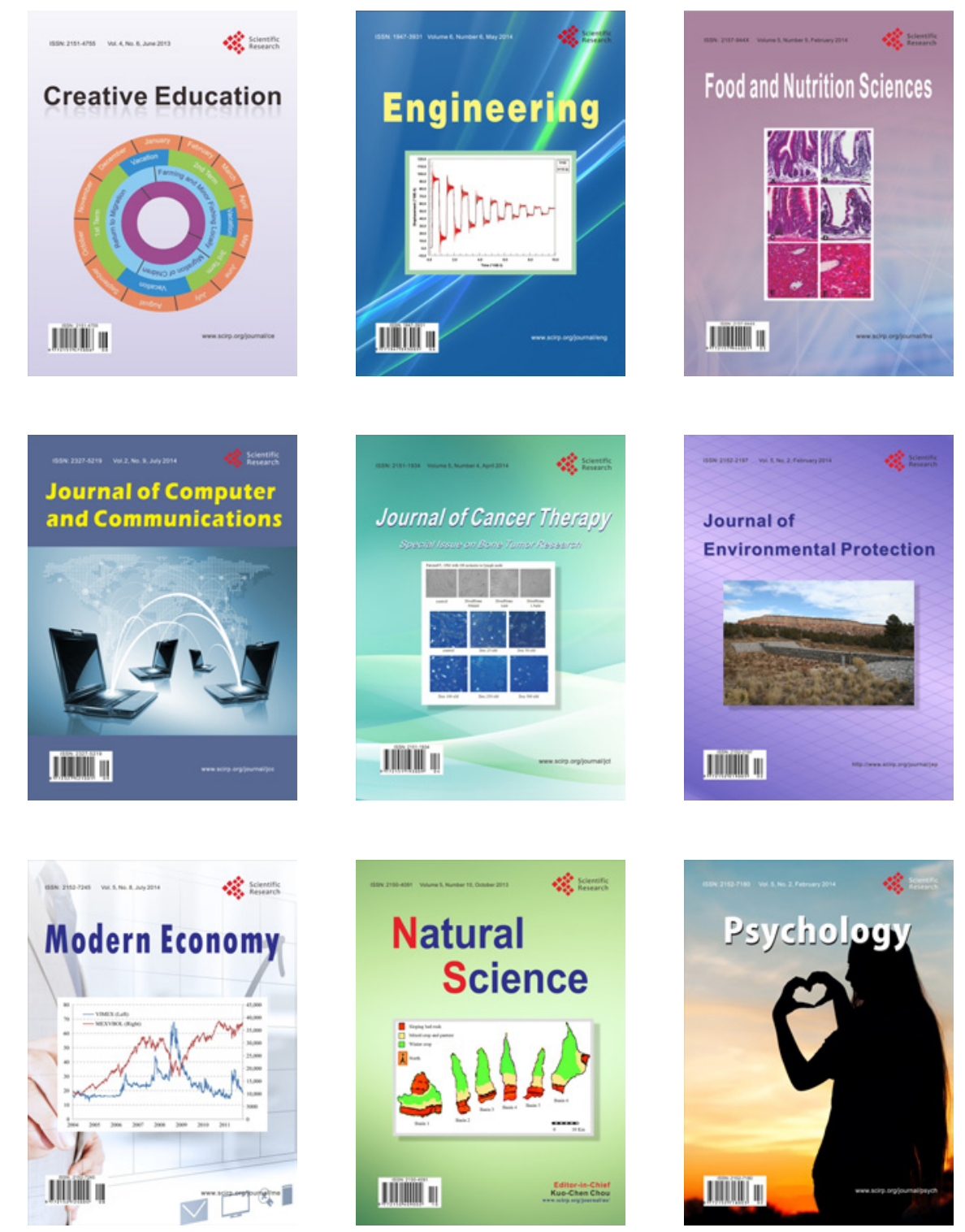